\title{
Transformation of the Spread of the Manunggaling Kawula lan Gusti Concept in Javanese Society from the 16th Century AD to the 21st Century AD
}

\author{
Dwi Afrianti \\ Pascasarjana UIN Sunan Gunung Djati Bandung \\ Email : Dafrianti@gmail.com
}

\begin{abstract}
The Manunggaling Kawula lan Gusti concept was found in Serat Nawa Ruci in the Middle Ages of Java in the 16th Century AD and was re-transformed into the New Javanese era in Dewa Ruci Fiber, Cabolek Fiber, Malaya Syeh Fiber until the 20th century AD in Fiber Sastra Jendra (Literature Aji Endra) which is still used today. Over five centuries, the concept experienced distortion of meaning far from the purpose and purpose of its writing. This study was analyzed using the theoretical basis of the R. G. Collingwood Historical Philosophy aimed to find out the development of Sufism in Java, the transformation of the spread of the concept in several Islamic Javanese texts derived from the Nawa Ruci Fiber, and its interpretation in the Fiber of Jendra's Literature. using historical research methods with heuristic steps, criticism, interpretation, and historiography. The manuscripts used obtained from utilizing manuscripts as a result of philological research or translation that have never been studied by others. This research found that in Indonesia, Sufi propagators of Islam in Java preached by combining local traditions with Islam, which led to the birth of Javanese Sufism.
\end{abstract}

Keywords: Transformation, Concepts, Javanese Society

\section{INTRODUCTION}

The themes or values raised are central concepts of Javanese civilization in general, namely Religion and Ethics, History and Mythology, Fiction, Science, Art, Social, Law, Folklore, Customs (Pigeaud, 2013). What Nawa Ruci wants to convey until it feels very important to be passed down continuously, starting from the Bima Suci in the 18th century AD in the Keraton Surakarta, whose contents and characterizations are adapted to the contemporary era are contained in the Fiber of Jendra Literature which was revealed to Suprapto Kadis, Murshid of the Qudusiyah Tariqa? The Bima Suci (1793 AD) was rewritten as Dewa Ruci (1803 AD), Fiber Cabolek (19th Century AD), Serat Centhini (1814 AD) written by Yosodipuro II, Serat Wirid Hidayati (1861 AD) composed by Ronggo Warsito, Suluk Syeh Malaya or Suluk Linglung (1884 AD) written by Iman Anom (Shasangka, 2014), and Sastra Jendra (1969 AD) written by Suprapto Kadis, tells the same thing, which is about the repentance of a human being who did not originally know God especially nafs because of the pile of sins due to following lust and lust so afraid of facing death, but then with the process of repentance nashuha which is not very easy, with His Grace to be our human being, or in Javanese terms is Manunggaling Kawula lan Gusti. Also referred to as science, which is known in the kufanah as 'dying before dying'.

The significance of the Manunggaling Kawula can Gusti concept of the Nawa Ruci Fiber, in addition to being shown through the continuity of the appearance of its derivative fibres, is also demonstrated by repeated copying and publishing by several copyists and publishers. Starting from a candid copy of the

* Copyright (c) 2019 Dwi Afrianti

This work is licensed under a Creative Commons Attribution-ShareAlike 4.0 International License.

Received: 5 December 2018; Revised: 21 December 2018; Accepted: 29 December 2018 
IJIK, Vol. 9 No. 1: 29-34

Transformation of the Spread of the Manunggaling Kawula lan Gusti Concept in Javanese Society from the 16th Century AD to the 21st Century AD

Dwi Afrianti

Bima Suci manuscript written by Yosodipuro I in 1793 in Old Javanese, then rewritten the new Javanese Dewa Dewa Ruci script in the Kawi script in the Macapat metrum in 1803.

In 1934, Serat Nawa Ruci written by Mpu Siwamurti was used as Dutch dissertation research by Prijohoetomo, professor of the Faculty of Literature, UGM, who received a doctorate in literature and philosophy at rijksuniversiteit in Utrecht, The Netherlands, with the title Nawaruci, whose subtitles were given. translated as "Introduction. Middle Javanese Text Prose Translation. Compared to Bimasuci in the Old Javanese metrum. " Prijohoetomo translates Fiber Nawa Ruci Mpu Siwamurti in Middle Javanese to New Javanese with the Tembang Gede meter (Old Javanese prosody), which is entitled "Bimasuci". The entire translation is in Dutch. In 1984, Adhikara translated the Dutch-language Nawa Ruci into Indonesian. In 2015, the Dolphin publisher published an Indonesian translation conducted by Dhamar Shashangka on the Dutch-language Nawa Ruci Prijohoetomo. The translation is accompanied by interpretation (Shashangka \& Murti, 2015).

In $1884 \mathrm{AD}$, the story of Dewa Ruci Yosodipuro I was adapted by Iman Anom in Fiber Suluk Lingling (Syeh Malaya), with the characterization of Sunan Kalijaga and the Prophet Khidr, into the Javanese language with Arabic script pegon. In 1992 it was translated by Muhammad Khafid Kasri. Iman Anom is a descendant of the 14th Sunan Kalijaga, a poet of Surakarta Sunanate (Anom, Kasri, \& Sunadji, 1993).

The significance is increasingly apparent when so much research on the Dewa Ruci Fiber, which produces theses, theses, dissertations, and books, but with fatal misunderstandings. Far from the meaning of "soul recognition". Meaning becomes wild. Some interpret as the King is the incarnation of God, and some consider it entered into the pantheistic or monistic understanding, which is considered as a doctrine of Islamic kejawen (Purnomo \& Masdiono, 2019).

Linking the Manunggaling Kawula lan Gusti concept with the Kejawen Islam in the wrong definition, the more obscure the meaning of the two terms. Moreover, followers of Kejawen Islam claim to be adherents of the Congregation but do not practice the main religious precondition, namely the implementation of the Shari'a. The concept of the introduction of the nafs even becomes fundamental for the emergence of psychology (psyche-logy) to find "the right man on the right place" for example the selection of fields of study for a high school graduate student who will continue to college, assessing whether a person by the field of work to be entered, and so forth, through aids in the form of a series of psychological test. But, with the meaning of psyche which has been reduced. It is no longer to know the soul (nafs) in the real sense, but to the psychological aspect which is more like ripples on the surface of the sea, while the nafs is in a depth that cannot be seen in plain view, because it is called, and more precisely, that psychology is a behavioral science, just observing overt behaviour. The term psyche itself is derived from the Greek word meaning "breath of life", symbolized as a butterfly. The butterfly is symbolized as a nafs that flies freely after experiencing self-forging in various stages up to the outside of the cocoon wrap which symbolizes the body. The narrowing of the meaning begins with the narrowing of the meaning of philosophy which is the mother of all sciences. In the West, the meaning of philosophy has been reduced to mere rationalism or empiricism which influences the way they look at themselves and the universe to the use of the sciences. The divorce between philosophy and spiritual practice in the West encourages efforts to differentiate between western philosophy and certain Islamic philosophies that provide similarities to the wisdom commonly used in Sufism which requires the perfection of the level of thought ('aql) and the sanctity of the nafs, although until now it still exists the grouping between the figures of mysticism and philosophy, and there are figures who are included in the two groups.

Observing all the problems above, it is increasingly evident that the meaning of Manunggaling Kawul lan Gusti from Fiber Dewa Ruci which means the same as Man 'Arofa Nafsahu Faqod' Arofa Rabbahu (Anyone who knows his nafs, will know his Rabb) from the hadith of the Prophet Muhammad saw., until now it has been twisted 
IJIK, Vol. 9 No. 1: 29-34

Transformation of the Spread of the Manunggaling Kawula lan Gusti Concept in Javanese Society from the 16th Century AD to the 21st Century AD

Dwi Afrianti

with understanding pantheism and monism. The result is fatal, because it conceals and even eliminates the vision of "Soul Recognition (nafs)" as the Purpose of Creation so that most human beings never try to find themselves intrinsic (nafs), which is the way to Know God that nafs and spirit have witnessed when in Alam Alastu. As Imam Ghazali said in the book "Kimiyatus Sa'adah", that the ultimate happiness of a human being is to know the nafs and Rabb. The shift in meaning is related to various misinterpretations of the terms syncretism, Javanese religion, Javanese mysticism, Javanese mysticism, and perhaps there are others, not to be separated from the misunderstanding of defining the concept of manunggaling kawan lust gusti by various communities, especially figures referred to as Geertz, Zoetmulder, Simuh, Ricklefs, Endraswara and others. All of these require further and lengthy study because the vision to be conveyed in the Dewa Ruci Fiber and derived fibre at different times and places are very important.

\section{RESEARCH METHODS}

The author will research on "Transforming the Spread of Manunggaling Kawul lan Gusti Concepts in Javanese Society from the 16th Century AD to $21 \mathrm{AD}$ ", by utilizing the results of other people's philological research on the script Nawa Ruci Fiber (16th Century AD) and Fiber Cabolek (Century Ages) 19th century AD), other people's translations of the text of Fiber Dewa Ruci (18th Century AD) and Serat Syeh Malaya (19th Century CE), and the writer's translation of the Fiber Literature Jendra (20th Century CE). This study shows a study in the field of History of Thought, therefore the writer will use the theoretical foundation of Historical Philosophy formulated by R. G. Collingwood (2004); that history is shaped by thoughts, and aims to know oneself. The author also uses the science of philology and uses a qualitative approach in describing the results of research (Sugiyono, 2013)

\section{RESULTS AND DISCUSSION}

Genealogy of the Transformation of the Concept of Myself and God from Nawa Ruci Fiber (16th Century) into Javanese Islamic Texts: Flesh of the Purified God (18th Century CE), Cabolek Fiber (19th Century), Malaya Syeh Fiber (19th Century), and Window Literature (20th Century)

\section{Bima Figure in Javanese perspective}

Taking a character in a story certainly has its reasons. Like Wrkudhara, also known as Arya Sena or Bima. Hereinafter referred to as Bima. The name Bima extends from ancient Java to New Java.

\section{Ancient Javanese Period}

In $908 \mathrm{AD}$ (830 saka), there was a Wukajana inscription, which contained the story of Bima. The first writing about the story of the Milky, which was done by order of Dyah Balitung, the King of Ancient Mataram, based in Central Java. In it is told that the Milky arrested Kicaka, and every puppet performance for the souls of ancestors, filled with Bhimma Kumaara's play contained in the story of the Indian Mahabharata (Farih, Hakim, \& Munir, 2016).

During the reign of Raja Dharmawangsa (991 - 1016 AD) of Isyana, based in East Java, some of the Sanskrit Mahabharata Indian parlours were adapted into Old Javanese (Rakhman, 2014). Bima is told here as a family protector, a protector of the community, a brave character, firm, and cruel (Rakhman, 2014). 
IJIK, Vol. 9 No. 1: 29-34

Transformation of the Spread of the Manunggaling Kawula lan Gusti Concept in Javanese Society from the 16th Century AD to the 21st Century AD

Dwi Afrianti

During the Kediri kingdom (1115 - 1130 AD), literature flourished, one of which was Bharatayudha kakawin written by Mpu Sedah and Mpu Panuluh during the reign of Raja Jayabhaya. In Bharatayudha's kakawin, Citra Bima is also portrayed as a formidable, abusive, and cruel war hero without mercy.

At this time it was indeed the time when the people glorified rescuers. At the same time as the last ancient type of inscriptions were made on the slopes of Mount Pananggungan, the adherents of the new school built the Sukuh Temple complex (1468 AD) and Ceta Temple (1475 AD) (Acri \& Griffiths, 2014) that looked strange on the slopes of Mount Lawu (border of East Java and Central Java). The temples are different from the temples of the Singasari or Panataran period, which functioned as a statue of a god. His description is interesting, although there is a residual influence from India. The most important characterizations are reliefs and statues depicting Bima and his younger brother Sadewa. Both appear in typical Javanese scenes. The depiction of the Bima as in the story of Nawa Ruci written in the Middle Java and Dewa Ruci or the Bima Suci in the New Java period. Sadewa's characterization is in the Sudamala manuscript, about his success in defeating Uma (the beautiful Parwati Goddess) from the curse that turned her into Durga (ugly) (Lombard, 1996).

\section{The Middle Javanese Period}

After the collapse of the Singasari kingdom, the Majapahit Kingdom emerged. Kakawin Nawa Ruci was written at this time, using Middle Javanese (Damayanti, 2015). During this period many statues and reliefs were made which depicted many Bima figures showing Bima with an open phallus. There are also phallus images on the Bima statue (Rahmadi, Jaferi, \& Djazimah, 2014).

In the 13th century there was a Bima Swarga manuscript in the form of prose, written in lontar; and in the form of poetry written in Balinese and Old Javanese, approaching Middle Java. There are three more fibres which speak Old Javanese in the form of songs.

\section{The New Java Period}

In this period, the story of Bima appeared in various forms in texts which always involved Bima with Dewa Ruci and the more assertive appearance of the concept of manunggaling kawula lust gusti, such as the rewritten Arjuna Wiwaha Fiber, Fiber Jatiswara which became a model for the writing of the Cabolang Fiber and Centhini Fiber, Cabolek Fiber, Bima Suci Fiber and Dewa Ruci Fiber. Serat Syeh Malaya depicts the figure of Bima in the figure of Sunan Kalijaga, and Dewa Ruci in the figure of the Prophet Khidr.

\section{Puppet (Oral Text) and Manuscript (Writing Text) as Da'wah Media}

Wayang or puppetry has existed since the 10th century AD, indicated by several inscriptions. The Balitung inscription (829 Saka $=907 \mathrm{AD}$ ) records a puppet performed for God (the galigi mawayang for Hyang macarita bimmaya kumara (Bima Kumara)). The Wilasrama inscription (852 Saka =930 AD), notes in Old Javanese, that there is a performance art called Wayang Wwang. The Wayang Wwang performance, which takes its certificate idea from epicentre Ramayana and Mahabharata, is contained in the Sumanasantaka kakawin composed by Mpu Monaguna. Puppet is known at least before $400 \mathrm{AD}$ because it is a product of Javanese animism culture.

A script may have been destroyed or has been damaged, but the community still remembers its contents and continues to be recited when caring for children as a means of education, until it is shown in puppets. Such manuscripts are called oral texts, which can be juxtaposed as written texts, which are not only written in the form of books, books, or fibres, but also as plays carved on stone as reliefs. There is a possible relationship between written texts, oral texts, and other works of art. Many written texts whose 
IJIK, Vol. 9 No. 1: 29-34

Transformation of the Spread of the Manunggaling Kawula lan Gusti Concept in Javanese Society from the 16th Century AD to the 21st Century AD

Dwi Afrianti

prototype is in the form of oral texts, and vice versa (Kamidjan, 2019). Written texts that require a deeper understanding, are filled with symbols known to the public, which are also widely displayed in wayang, as a means of communicating information more effectively and efficiently.

The saints carried out the spread of Islam using art media, as a way of communicating effectively in the Middle Javanese period which was still exposed to the remnants of pre-Islamic, Hindu-Buddhist times, namely by binding local traditions with Islam, giving birth to new forms of art that contained a vision of Islamic teachings.

The results of the trustees' meeting with Raden Patah on art media that will be used as a means of conveying Islamic teachings, decided that the way of the Javanese animism period to Hindu-Buddhist needs to be continued with certain changes that are adapted to conditions when Islam has entered and spread on the island of Java, because it can be used as a medium for good preaching; puppet-like forms of statues like humans must be reformed because depictions of people are forbidden in Islam; the stories of gods must be changed and filled with teachings that contain the vision of Islam to get rid of polytheism; puppet stories must contain aqidah, worship, and morals; Wayang stories composed by Walmiki and Wiyasa must be changed into the vision of Islam; characterization of the previous puppet and the events contained therein are used as symbols which are interpreted in accordance with Islamic teaching; puppet performances must be carried out in an orderly and polite manner, away from all forms of disobedience; all the elements of the puppet including gamelan and the names of the macapat song must have a meaning that is in accordance with Islamic da'wah, carried out systematically in order to be understood correctly and well (Kamidjan, 2019).

At the beginning of Demak's power, wayang puppets were drawn two-dimensionally flat by avoiding the impression of the human form. Puppet is a body that is cut into pieces with hands together with the body. In the 16th century, Sunan Kalijaga made his hands move. The colours and puppet accessories also have meaning.

Sunan Kalijaga plays the story of Dewa Ruci as a means of Islamic preaching, which refers to the Fiber of Nawa Ruci written by Mpu Siwamurti in Middle Java / Why did Sunan Kalijaga change the name "Nawa" Ruci to "Dewa" Ruci, an interesting question.

Mpu Siwamurti wrote in the Java-Bali period or the Middle Javanese period that the dominance of India and Hindu-Buddhist religions still strengthened, while Dewa Ruci was cast by Sunan Kalijaga in the New Javanese Period (Khalimi \& Khaer, 2013) when the contents of India and Hindu-Buddhism began to fade by replacing the massive spread of Islam. Nawa connotes polytheism, consisting of 9 gods, which is interpreted as 9 gods. While Gods can be interpreted as God, or Supreme God, by Islamic monotheism with the monotheistic concept, that God is Almighty. The name "Ruci" was not replaced by Sunan Kalijaga, because it has the meaning of the Holy Spirit.

\section{CONCLUSION}

Various nations and religions. In Islam, the hadith of the Messenger of Allah (may peace be upon him) saw. narrated by Ali bin Abi Talib, "Man 'Arofa Nafsahu faqod' Arofa Rabbahu", "Whoever knows his soul, will know his God", is a well-known hadith in the satirical tradition, as it is the purpose of the creation of beings witnessed between the soul and the soul with Rabb when he was in Alastu Nature. When it becomes a destination, all directions are taken there. A. H. Johns's thesis proves that the bearers and distributors of Islam in Indonesia are Sufis, because they are capable of subtly compromising local traditions with Islam, including in Java. Like a clear Ocean, Islam, wherever it is, the contents of the glass 
IJIK, Vol. 9 No. 1: 29-34

Transformation of the Spread of the Manunggaling Kawula lan Gusti Concept in Javanese Society from the 16th Century AD to the 21st Century AD

Dwi Afrianti

will have a colour that corresponds to the area it enters. In Java, the concept appeared in the 16th century CE in terms of my own and mysticism found in the Nawa Ruci Fiber, and transformed by the spirit of the later ages, into the Holy Rifle (18th Century) or the God of Purification (19th Century Century), Cabolek Fiber (19th Century Century), Malaya Sheath (19th Century Century), but it has lost its significance. Today, the concept is dropped into the Letters of General Literature (1969, $1988 \mathrm{M})$.

\section{REFERENCES}

Acri, A., \& Griffiths, A. (2014). The Romanisation Of Indic Script Used In Ancient Indonesia. Bijdragen Tot De Taal-, Land-En Volkenkunde/Journal Of The Humanities And Social Sciences Of Southeast Asia, 170(2-3), 365-378.

Anom, I., Kasri, M. K., \& Sunadji, K. W. (1993). Suluk Linglung Sunan Kalijaga (Syeh Melayu): Karangan, Iman Anom Tahun 1806 Çaka/1884 Masehi Di Surakarta. Balai Pustaka.

Collingwood, R. G. (2004). Filsafat Sejarah: Investigasi Historis Dan Arkeologis. Yogyakarta: Insight Reference.

Damayanti, F. (2015). Pemerintahan Wisnuwardhana Ditinjau Dari Segi Politik Dan Keagamaan (1248-1268). Avatara, 4(1).

Farih, M. I., Hakim, L., \& Munir, M. (2016). Segmentasi Citra Wayang Dengan Metode Otsu. CyberTechn.

Kamidjan, K. (2019). Penentuan Usia Naskah Pada Penelitian Filologi. Jumantara: Jurnal Manuskrip Nusantara, 9(1), 147-177.

Khalimi, K., \& Khaer, A. (2013). Tata Nilai Perdamaian Sufistik Jawa Cerita Pewayangan. Jurnal Pendidikan Dan Kebudayaan, 19(1), 18-30.

Lombard, D. (1996). Nusa Jawa: Silang Budaya: Kajian Sejarah Terpadu. Gramedia Pustaka Utama.

Pigeaud, T. G. T. (2013). Literature Of Java (Vol. 3). Springer Science \& Business Media.

Purnomo, A. D., \& Masdiono, T. (2019). Menggali Khasanah Tradisi Lisan Ke Dalam Medium Visual Folklor Sunda Sebagai Sumber Ide Buku Seni (Artist's Book). Seminar Nasional Seni Dan Desain 2019, 47-53. State University Of Surabaya.

Rahmadi, R., Jaferi, A. R., \& Djazimah, N. (2014). Dinamika Pemikiran Sarjana Muslim Tentang Metodologi Studi Agama Di Indonesia: Kajian Terhadap Literatur Terpublikasi Tahun 19642012. Tashwir, Jurnal Penelitian Agama Dan Sosial Budaya, 1(2).

Rakhman, A. K. (2014). Sebuah Rupa "Jawa” Dalam Kalangwang. Jurnal Poetika, 2(1).

Shasangka, D. (2014). Induk Ilmu Kejawen: Wirid Hidayat Jati. Pringadi Abdi Surya.

Shashangka, D., \& Murti, S. (2015). Ilmu Jawa Kuno: Sanghyang Tattwajñāna Nirmala Nawaruci. Dolphin.

Sugiyono. (2013). Metode Penelitian Pendidikan Pendekatan Kauntitatif, Kualitatif Dan R\&D. Bandung: Alfabeta. 